Acta Agroph., 2020, 27, 17-29

doi: $10.31545 /$ aagr/125618

\title{
ESTIMATION OF POSSIBILITY OF USE OF FLOUR FROM GRAIN OF COMMON WHEAT WINTER CULTIVARS FROM ORGANIC FARMING AS RAW MATERIAL FOR PASTA PRODUCTION
}

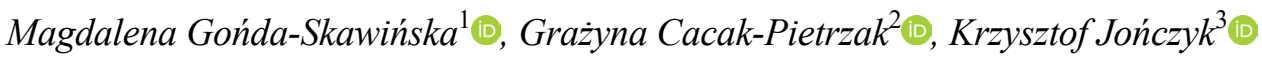 \\ ${ }^{1}$ Department of Grain Processing and Bakery, Prof. Wacław Dąbrowski Institute of Agricultural \\ and Food Biotechnology, Poland \\ ${ }^{2}$ Division of Fruits, Vegetables and Cereals Technology, Warsaw University of Life Sciences, Poland \\ ${ }^{3}$ Department of Systems and Economics of Crop Production, Institute of Soil Science and Plant \\ Cultivation, State Research Institute, Poland \\ e-mail: magdalena.gonda@ibprs.pl
}

Abstract. The paper presents the results of estimation of the possibility of using flour from the grain of 13 winter cultivars of common wheat (Akteur, Alcazar, Batuta, Bogatka, Boomer, Jantarka, Jenga, Kohelia, Legenda, Mateja, Natula, Ostka Strzelecka, Ostroga) cultivated under the conditions of organic farming as raw material for pasta production. The scope of the study covered the evaluation of dough susceptibility to darkening, pasta preparation, estimation of selected chemical components, and of the culinary and sensory quality of the pasta. It was found that a majority of pasta doughs were characterised by medium susceptibility to darkening, and none of the pasta doughs was classified in the group with low susceptibility to darkening. The requirements of the pasta industry regarding that parameter were not met in the case of flour from the grain of 4 wheat cultivars (Alcazar, Jenga, Legenda, Nateja). All the pastas were characterised by a low total protein content, typical for products from organic raw materials (8.3-9.8\% DM), and a low content of minerals (0.49-0.61\% DM). They were characterised by good culinary quality - pasta dry matter losses during cooking ranged from 3.1 to $6.5 \%$, and the values of the weight increase index from 2.9 to 3.2. Based on the results obtained, flour from the grain of the cultivars Bogatka and Natula was selected as potential raw material for pasta production.

Keyw ords: winter wheat, organic farming, pasta, culinary quality, sensory quality

\section{INTRODUCTION}

Next to bread, pasta is the most popular cereal product. In recent years, the annual consumption of pasta in Poland is at the level of approx. $5 \mathrm{~kg} /$ person and displays an increasing trend (GUS 2020). The best raw material for pasta production is semolina - pasta flour obtained from the grain of durum wheat (Triticum durum). Durum wheat is a species cultivated in regions with warm climate and a small amount of precipitations (Asia, North America, Australia, Africa, the south of Europe), and hence its availability in many countries, including Poland, is 
limited. The local pasta producers import the grain of durum wheat or the products of its millling, use flour from the grain of common wheat (Triticum aestivum) for pasta production, or else use mixtures of semolina with products of milling of grain of common wheat (Obuchowski 1997, Rachoń et al. 2002).

Common wheat is a cereal commonly cultivated in Poland, also in organic farms. Wheat grain from organic farming can be a good raw material for the production of flour for baking purposes (Cacak-Pietrzak et al. 2008). Undertaking the present study, it was assumed that certain cultivars of common wheat cultivated under organic farming conditions can be used to obtain flours with quality meeting the requirements of pasta industry.

The objective of the study was to estimate the possibility of using flour from the grain of winter cultivars of common wheat cultivated under organic framing conditions as raw material for the production of pasta.

\section{MATERIAL AND METHOD}

The test material consisted of flours from the milling of grain of 13 winter cultivars of common wheat: Akteur, Alcazar, Batuta, Bogatka, Boomer, Jantarka, Jenga, Kohelia, Legenda, Nateja, Natula, Ostka Strzelecka, Ostroga, and of pasta produced from those flours in laboratory conditions. The wheat grain originated from the Osiny Experimental Station (IUNG-PIB Puławy), from cultivation conducted in organic conditions.

Wheat grain was ground to low extraction flours (extraction rates of $70-72 \%$ ) using a laboratory mill Quadrumat Senior from Brabender. The first stage of estimation of the possibility of using the flours as a pasta raw material consisted in the determination of the susceptibility of the prepared pasta doughs to darkening, on the basis of dough colour change during a 3-hour thermostating at $30^{\circ} \mathrm{C}$ (Obuchowski 1997). Dough colour change was evaluated visually, using as three-degree scale: I (no darkening), II (slight darkening), III (strong darkening), and instrumentally, by means of a Minolta CR-200 photocolorimeter, in the CIE L*a*b* system. Based on the change of colour components before and after the temperature cycle, the absolute colour difference $(\Delta \mathrm{E})$ was calculated (Romankiewicz et al. 2017).

In the next stage, a Kitchen Aid dough mixer was used to prepare pasta doughs with moisture of $36 \%$ ( $300 \mathrm{~g}$ of flour, tap water with temperature of $30^{\circ} \mathrm{C}$ ). The prepared dough was rolled to the thickness of $2 \mathrm{~mm}$ and cut to the form of spaghetti by means of a Kitchen Aid attachment, then formed into nests and dried in a convection drier at $60^{\circ} \mathrm{C}$ to water content at the level of $12 \%( \pm 0.1 \%)$.

In the ready dried pastas the content of basic chemical components was determined, i.e.: total protein with the Kjeldahl method (N·5,7) using the Kjeltec 8200 apparatus from the company Foss (PN-EN ISO 20483:2014-02), total ash content 
(PN-EN ISO 2171:2010), and the hardness of the pastas was tested using the TA-XT2i texture analyser made by StableMicro System. In the shear test a tooth-shaped shear head with nominal force of $0.5 \mathrm{~N}$ was used, and the feed rate of the head was $0.1 \mathrm{~mm} \mathrm{~s}^{-1}$. The results of measurements were recorded in the program Texture Expert Exceed (Operation Manual 1997).

Samples of pasta with mass of $100 \mathrm{~g}$ were cooked in $1000 \mathrm{~cm}^{3}$ of salted $(5 \mathrm{~g}$ of kitchen salt) tap water. The optimum cooking time was determined individually for each sample on the basis of the time required for the core in the pasta cross-section to disappear. After the cooking, the culinary properties of the pasta were evaluated on the basis of dry matter loss during cooking and of the value of the weight increase index (Obuchowski 1997). In addition, the texture profile analysis (TPA) was conducted by means of the TA-XT2i texture analyser from the company StableMicro System. A cylindrical probe (Ø $25 \mathrm{~mm})$ was used for the measurement. The feed rate of the working element was $1 \mathrm{~mm} \mathrm{~s}^{-1}$, the gap between the clamps of the compressing element was $10 \mathrm{~s}$, and the degree of compression of the sample was 30 and $70 \%$. The graphs obtained were used to determine the texture parameters, such as springiness, cohesiveness, hardness, gumminess and chewiness (Petitot et al. 2009). Sensory evaluation of the cooked pastas was also performed. For every evaluated component (shape, colour, appearance, flavour and taste, other features) notes were assigned, from 1 (undesirable) to 5 points (highly desirable). The results are presented in the paper as mean values of those component features. The sensory evaluation was performed by a 15 -person team of trained jurors.

The results were processed statistically using the single-factor analysis of variance ANOVA, at significance level of $\alpha=0.05$. Homogeneous groups were determined with the use of Tukey's t-test. All analyses were performed in three replicates. Statistical analysis of the results was performed in the program Statgraphics Centurion XVI.

\section{RESULTS AND DISCUSSION}

One of the most important quality parameters of pasta is its colour. Pasta colour depends on the colour of the raw materials used (flour/semolina) and on the parameters of the production process. Pasta colour is strongly affected by the content of minerals (ash) in the flour/semolina, its level being related to the amount of those components in the grain used for milling and in the flour extract. The higher the ash content of the flour, the darker its colour, which results from a higher content of fragmented elements of the seed-coat (Joubert et al. 2018). In the case of low-extract flours (light-coloured), the colour of pasta is strongly affected by the susceptibility of the pasta dough to darkening. Dough darkening is related with the activity of tyrosinase - an enzyme from the group of hydrolases. Under the effect of that enzyme, in the presence of oxygen, melanins - substances with dark colouring, 
are formed from the amino acid tyrosine. Evaluation of pasta dough colour change is one of the basic criteria for the choice of low-extract flours as raw material for pasta production (Rachoń 2004, Sicignano et al. 2015).

Pasta doughs prepared from the analysed flours displayed significant differentiation in terms of colour lightness (Tab. 1). The values of that parameter, evaluated immediately after the preparation of the doughs, fell within the range from 79.99 and 83.43 (mean of 82.26). After the 3-hour thermostating, they decreased to the level of 72.25-77.79 (mean of 75.96), which indicates unfavourable darkening of their colour (change in the direction of grey).

The values of colour parameter $\mathrm{a}^{*}$ of the analysed pasta doughs were statistically significantly differentiated (Tab. 1). Immediately after the preparation of the doughs those values were from -0.90 to 0.31 . After the 3 -hour thermostating, the values of that parameter increased (0.19-1.60), which indicates an increase of the contribution of the red colour.

The values of colour parameter $b^{*}$ of the analysed pasta doughs were also statistically significantly differentiated (Tab. 1). Immediately after the preparation of the doughs those values were from 14.30 to 17.50 . After the 3-hour thermostating, the values of that parameter usually decreased (except for doughs from flour from the grain of cultivars Alcazar and Nateja), which indicates a decrease of the contribution of the yellow colour.

The absolute colour difference $\Delta \mathrm{E}$ of the pasta doughs before and after the thermostating significantly differentiated the analysed material and its average value amounted to 6.5 (Tab. 1). All analysed samples of pasta dough were characterised by $\Delta \mathrm{E}$ values above 3.5 , which according to the criterion of the International Commission on Illumination (CIE) (Romankiewicz et al. 2017) means that the changes in their colour that took place during the temperature cycle were significant - identifiable even for an inexperienced observer. The least colour changes were noted in the case of doughs from flours from the grain of cultivars Natula, Bogatka, Ostka Strzelecka and Jantarka ( $\Delta \mathrm{E}$ from 5.5 to 5.9), and the greatest in the case of cultivars Alcazar and Nateja ( $\Delta E$ of 7.9 and 7.6, respectively). Unfavourable changes of colour of pasta doughs prepared from low-extract flours from common wheat grain are also indicated by the results of studies by Rachon et al. (2002) and Gońda et al. (2018).

The results of instrumental evaluation of colour change of the pasta doughs were partially supported by the results of the visual evaluation. None of the analysed dough samples was classified in the group with low susceptibility fo darkening (degree I) (Tab. 1). Most of the samples were characterised by medium susceptibility to darkening (degree II), and in the case of 4 samples of dough their susceptibility to darkening was high (degree III). Those were doughs prepared from flour from the grain of cultivars Alcazar, Jenga, Legenda and Nateja. According to the 


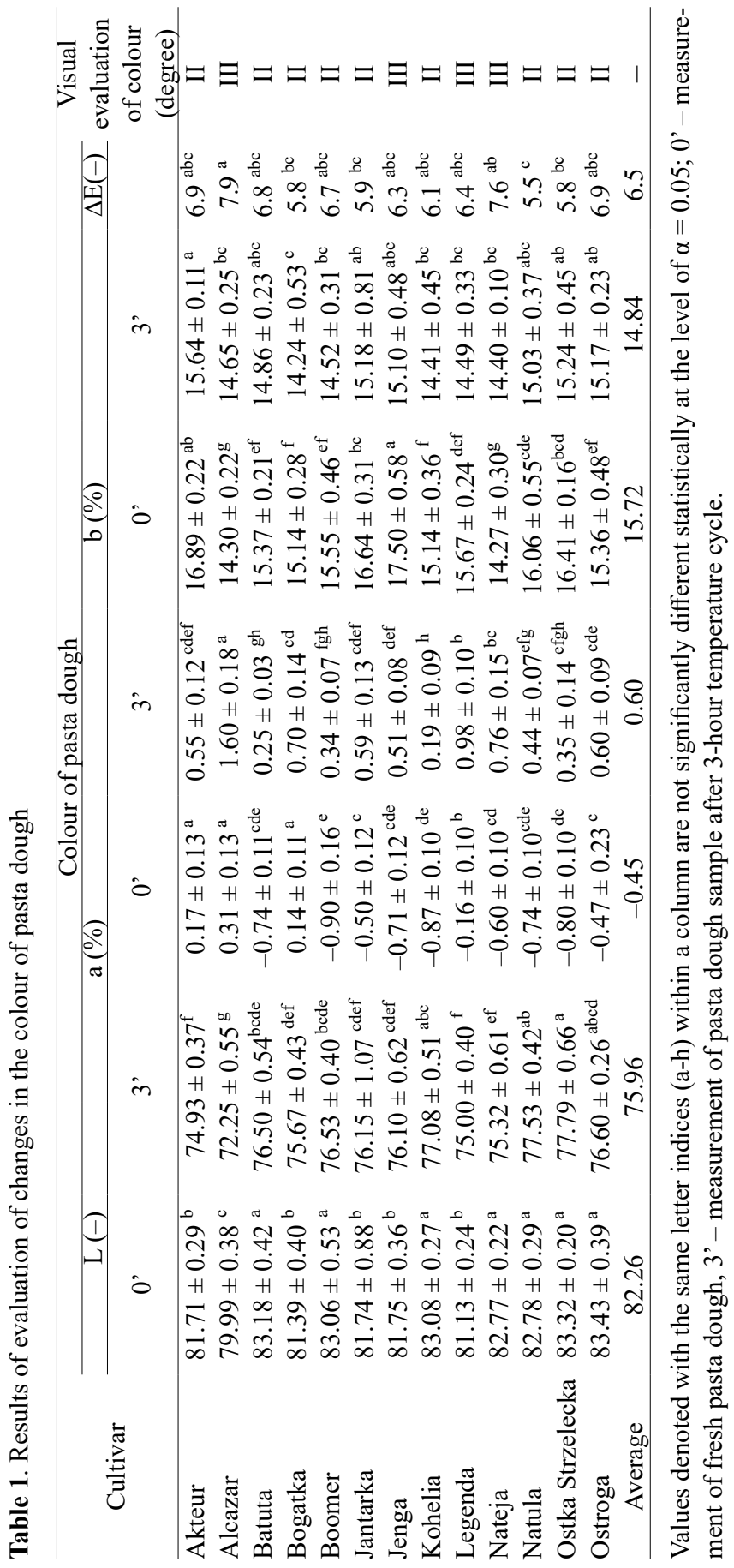


standard PN-A-74020:1993, flours producing doughs with an excessive susceptibility to darkening should not be used for pasta production. On that basis it was concluded that flours from the abovementioned wheat cultivars did not meet the requirements for pasta raw materials.

The content of minerals in the analysed pastas ranged from 0.49 to $0.61 \% \mathrm{DM}$, and the differences noted were statistically significant (Tab. 2). The lowest ash content was characteristic of pasta prepared from flour from grain of the cultivar Kohelia, and the highsest - from that of Jantarka. Similar ash content levels to those obtained in this study $(0.54-0.64 \% \mathrm{DM})$ were noted in the case of organic pastas from flour of the grain of common wheat cultivars analysed by Gońda et al. (2018). In a study by Sobota and Skwira (2009), on the other hand, it was demonstrated that the content of minerals in popular pastas is usually in the range of $0.45-0.50 \% \mathrm{DM}$, which results from the commong use of flours of type not higher than 500 in their production. A higher content of minerals in pasta raw material causes not only a deterioration of the pasta colour, but can also lead to a deterioration of its culinary quality (Vetrimani et al. 2005, Bagdi et al. 2014, Biernacka et al. 2018, Joubert et al. 2018).

Table 2. Results of estimation of physiochemical and physical properties of pasta

\begin{tabular}{lccc}
\hline \multicolumn{1}{c}{ Cultivar } & $\begin{array}{c}\text { Total ash content } \\
(\% \mathrm{DM})\end{array}$ & $\begin{array}{c}\text { Total protein content } \\
(\mathrm{Nx} 5,7)(\% \mathrm{DM})\end{array}$ & Hardness $(\mathrm{N})$ \\
\hline Akteur & $0.60 \pm 0.02^{\mathrm{abc}}$ & $9.7 \pm 0.7^{\mathrm{a}}$ & $21.1 \pm 3.59^{\mathrm{d}}$ \\
Alcazar & $0.60 \pm 0.01^{\mathrm{ab}}$ & $9.8 \pm 0.5^{\mathrm{a}}$ & $33.0 \pm 1.60^{\mathrm{ab}}$ \\
Batuta & $0.54 \pm 0.00^{\mathrm{de}}$ & $9.0 \pm 0.2^{\mathrm{a}}$ & $23.6 \pm 3.38^{\mathrm{cd}}$ \\
Bogatka & $0.58 \pm 0.01^{\mathrm{bcd}}$ & $8.7 \pm 0.5^{\mathrm{a}}$ & $10.1 \pm 0.73^{\mathrm{e}}$ \\
Boomer & $0.54 \pm 0.01^{\mathrm{de}}$ & $8.6 \pm 0.2^{\mathrm{a}}$ & $30.8 \pm 2.26^{\mathrm{ab}}$ \\
Jantarka & $0.61 \pm 0.01^{\mathrm{a}}$ & $8.3 \pm 0.6^{\mathrm{a}}$ & $12.4 \pm 1.35^{\mathrm{e}}$ \\
Jenga & $0.58 \pm 0.01^{\mathrm{bcd}}$ & $8.6 \pm 0.4^{\mathrm{a}}$ & $9.4 \pm 1.01^{\mathrm{e}}$ \\
Kohelia & $0.49 \pm 0.01^{\mathrm{f}}$ & $8.5 \pm 0.4^{\mathrm{a}}$ & $31.0 \pm 2.26^{\mathrm{ab}}$ \\
Legenda & $0.60 \pm 0.01^{\mathrm{abc}}$ & $9.2 \pm 0.7^{\mathrm{a}}$ & $13.8 \pm 2.16^{\mathrm{e}}$ \\
Nateja & $0.51 \pm 0.01^{\text {ef }}$ & $8.5 \pm 0.4^{\mathrm{a}}$ & $33.6 \pm 2.77^{\mathrm{a}}$ \\
Natula & $0.56 \pm 0.01^{\mathrm{cd}}$ & $8.7 \pm 0.1^{\mathrm{a}}$ & $29.8 \pm 2.71^{\mathrm{ab}}$ \\
Ostka Strzelecka & $0.51 \pm 0.00^{\text {ef }}$ & $8.7 \pm 0.2^{\mathrm{a}}$ & $33.3 \pm 0.68^{\mathrm{a}}$ \\
Ostroga & $0.51 \pm 0.00^{\text {ef }}$ & $9.1 \pm 0.4^{\mathrm{a}}$ & $28.2 \pm 1.82^{\mathrm{bc}}$ \\
\multicolumn{1}{c}{ Average } & 0.56 & $8.9^{2}$ & 23.9 \\
\hline
\end{tabular}

Values denoted with the same letter indices (a-f) within a column are not significantly different statistically at the level of $\alpha=0.05$.

Protein content, apart from the nutritive value, affects also the quality parameters of pasta. Too low a content of that component causes that pasta is more brittle and susceptible to damage during transport and storage, will overcook faster, larger amounts of dry matter will migrate to the solution, and the pasta will be more viscous and less firm (Baiano et al. 2007, Bagdi et al. 2014, Joubert et al. 2018). 
Total protein content in the analysed pastas ranged from 8.3 to $9.8 \% \mathrm{DM}$ (mean of $8.9 \% \mathrm{DM}$ ), and the differences in the level of that component were not statistically significant (Tab. 2). From the technological viewpoint, taking into account protein content, the highest evaluated were the pastas prepared from flour from the grain of cultivars Alcazar and Akteur, and the lowest - from the cultivar Jantarka. The relatively low total protein content in the pastas resulted from the low level of that component in the flours which were the basic raw material for their preparation. Those were flours from the grain of common wheat from organic farming, where it is forbidden to use nitrogen fertilisers easily assimilable by plants. Wheat cultivated under organic farming conditions is characterised by a lower content of protein substances compared to wheat from intensive cultivation (Marzec et al. 2011, Dziki et al. 2017).

Gońda et al. (2018) analysed organic pastas from flour from the grain of spring wheat cultivars and obtained somewhat higher values of total protein content (8.6$10.3 \% \mathrm{DM}$ ). This results from a higher content of protein substances in the grain of spring wheat cultivars, relative to winter wheat cultivars, which finds support in numerous studies (Klepacka and Fornal 2008, Leszczyńska 2010, Stępniewska 2016). In commercial organic pastas analysed by Cacak-Pietrzak et al. (2016) the content of total proteins was higher, ranging from 10.7 to $14.7 \% \mathrm{DM}$, but the raw materials used in their production were e.g. spelt flour and semolina from durum wheat, which contain more protein substances than flours from common wheat.

According to Wójtowicz (2006), pasta hardness depends on the kind of raw material used for its production, higher hardness being characteristic of pastas from the products of milling of durum wheat than of soft wheats. Piwińska et al. (2016) demonstrated that pasta hardness is affected by the conditions of the process of drying. In our study, the hardness of dried and ready pastas ranged from 9.4 to $33.3 \mathrm{~N}$ and it was statistically differentiated (Tab. 2). The highest hardness was characteristic of pastas prepared from flour from the grain of cultivars Alcazar, Nateja and Ostka Strzelecka, and the lowest - of pastas from flout from the grain of cultivars Bogatka, Jantarka, Jenga and Legenda. In a study by Gońda et al. (2018), the values of that parameter for organic pastas from flour from the grain of spring wheat cultivars were also highly varied (17.5-37.9 N).

The values of the weight increase index, indicating the capacity of pasta to increase its mass during cooking, ranged from 2.9 to 3.2 (Tab. 3). No statistically significant differentiation of the analysed samples was noted in this respect. Similar values of the parameter in question (2.9-3.3) were obtained by Gońda et al. (2018) during their evaluation of organic pastas prepared in laboratory conditions from flour from the grain of spring cultivars of common wheat. Much more diverse weight increase was characteristic of commercial organic pastas studied by Cacak-Pietrzak 
et al. (2016). Those authors demonstrated that the values of that parameter depended on the kind of raw material used for pasta production and ranged from 1.9 (durum wheat pasta) to 3.1 (wholemeal rye pasta).

Table 3. Results of evaluation of culinary and sensory properties of pasta

\begin{tabular}{lccc}
\hline \multicolumn{1}{c}{ Cultivar } & $\begin{array}{c}\text { Weight increase index } \\
(-)\end{array}$ & $\begin{array}{c}\text { Dry matter losses of } \\
\text { pasta during cooking } \\
(\%)\end{array}$ & $\begin{array}{c}\text { Sensory evaluation } \\
(\text { pts. })\end{array}$ \\
\hline Akteur & $3.0 \pm 0.1^{\mathrm{a}}$ & $4.5 \pm 0.0^{\mathrm{c}}$ & $4.2 \pm 0.9^{\mathrm{a}}$ \\
Alcazar & $2.9 \pm 0.1^{\mathrm{a}}$ & $6.5 \pm 0.7^{\mathrm{a}}$ & $4.5 \pm 0.8^{\mathrm{a}}$ \\
Batuta & $3.0 \pm 0.1^{\mathrm{a}}$ & $3.1 \pm 0.0^{\mathrm{d}}$ & $4.0 \pm 0.5^{\mathrm{a}}$ \\
Bogatka & $3.2 \pm 0.1^{\mathrm{a}}$ & $5.2 \pm 0.0^{\mathrm{bc}}$ & $4.5 \pm 0.7^{\mathrm{a}}$ \\
Boomer & $3.2 \pm 0.1^{\mathrm{a}}$ & $6.2 \pm 0.0^{\mathrm{ab}}$ & $4.3 \pm 0.6^{\mathrm{a}}$ \\
Jantarka & $3.1 \pm 0.1^{\mathrm{a}}$ & $5.4 \pm 0.8^{\mathrm{abc}}$ & $4.4 \pm 0.7^{\mathrm{a}}$ \\
Jenga & $3.2 \pm 0.0^{\mathrm{a}}$ & $5.8 \pm 0.0^{\mathrm{ab}}$ & $4.4 \pm 0.8^{\mathrm{a}}$ \\
Kohelia & $3.1 \pm 0.1^{\mathrm{a}}$ & $6.5 \pm 0.0^{\mathrm{a}}$ & $4.3 \pm 0.7^{\mathrm{a}}$ \\
Legenda & $3.0 \pm 0.1^{\mathrm{a}}$ & $5.6 \pm 0.0^{\mathrm{abc}}$ & $4.3 \pm 0.7^{\mathrm{a}}$ \\
Nateja & $2.9 \pm 0.1^{\mathrm{a}}$ & $6.4 \pm 0.0^{\mathrm{ab}}$ & $4.4 \pm 0.5^{\mathrm{a}}$ \\
Natula & $3.0 \pm 0.1^{\mathrm{a}}$ & $5.2 \pm 0.0^{\mathrm{bc}}$ & $4.5 \pm 0.6^{\mathrm{a}}$ \\
Ostka Strzelecka & $3.0 \pm 0.1^{\mathrm{a}}$ & $5.8 \pm 0.0^{\mathrm{ab}}$ & $4.1 \pm 0.7^{\mathrm{a}}$ \\
Ostroga & $3.0 \pm 0.1^{\mathrm{a}}$ & $6.0 \pm 0.0^{\mathrm{ab}}$ & $3.9 \pm 0.7^{\mathrm{a}}$ \\
\multicolumn{1}{c}{ Average } & $3.0^{\mathrm{a}}$ & $5.6^{2}$ & $4.3^{2}$ \\
\hline
\end{tabular}

Explanatory notes as in Tab. 2.

Dry matter losses of pasta during cooking should not exceed 7-8\% (Özyurt et al. 2015, Piwińska et al. 2016). For the analysed pastas the losses ranged from 3.1 to $6.5 \%$, and the differences between the mean values were statistically significant (Tab. 3). The lowest dry matter loss was noted for the pasta from flour from the grain of cultivar Batuta (3.1\%), and the largest amount of dry matter migrated to the solution during the cooking of pasta from flour from the grain of cultivars Alcazar and Kohelia (6.5\%) and Nateja (6.4\%). It can be accepted, therefore, that the analysed pastas were characterised by low dry matter losses, which indicates their good quality. The values of the parameter in question obtained in this study were similar to the results obtained in a study by Gońda et al. (2018) for organic pastas from the grain of spring cultivars of common wheat. Greater losses of dry matter were characteristic of pastas from flour from the grain of common wheat analysed in a study by Ma et al. (2014), and pastas from flour from the grain of durum wheat analysed by Özyurt et al. (2015). According to Mondelli (2004) and to Deng and Manthey (2017), dry matter losses depend to a high degree on the content and quality of protein substances in the raw material used for pasta production.

The team performing the sensory evaluation of the pastas had no reservations regarding their taste and flavour. After cooking, the pastas retained their shape, without conglomeration. The mean number of points for the evaluated sensory features 
varied from 3.9 to 4.5 pts. (Tab. 3). The highest rated was the pasta produced from flour from the grain of the wheat cultivar Ostroga. Reservations related to the consistency and colour of the pasta sample, white-creamy tending to grey. A creamy colour with a noticeable grey hue was also characteristic of pastas produced from flour from the grain of wheat cultivars Alcazar, Nateja and Legenda. The colour of the remaining pastas was uniformly creamy, typical for products obtained from flour from the grain of common wheat. The endosperm of common wheat contains less carotenoid pigments compared to the endosperm of durum wheat, and therefore pastas from that raw material do not have the natural amber colouring, valued by the consumers (Rachoń 2004).

Texture analysis is an important criterion in the evaluation of the overall quality of cooked pasta. Textural properties of the product play the main role in its ultimate acceptance by the consumer. Good quality pasta should be characterised by suitable firmness, springiness, smooth surface and limited stickiness (Gull et al. 2015, Biernacka et al. 2017).

Springiness is an indicator of the degree of the product's return to its original shape after compression (Petitot et al. 2009). Springiness of the analysed pastas varied from 0.55 to 0.83 and it was statistically varied (Tab. 4). A similar level of springiness $(0.68-0.84)$ was characteristic of organic pastas produced from flour from the grain of spring cultivars of wheat analysed by Gońda et al. (2018) and organic pastas from wholemeal flour analysed by Olivera and Salvadori (2009).

Cohesiveness is an indicator on the basis of which we evaluate the retention of the shape of pasta during cooking (Dziki et al. 2012). Cohesiveness of the analysed pastas varied from 0.28 to 0.49 , and its variation was not statistically significant (Tab. 4). Similar results were noted by Gońda et al. (2018) who evaluated organic pastas from flour of the grain of spring wheat cultivars. A somewhat higher cohesiviness was characteristic of wholemeal organic pastas analysed by Olivera and Salvadori (2009), semolina pastas studied by Petitot et al. (2009), and common wheat pasta analysed by De Marco et al. (2014).

Hardness corresponds to the force required for the compression of a strand of pasta between molar teeth (Petitot et al. 2010). The hardness of the analysed pastas varied from 2.41 to $8.10 \mathrm{~N}$ and it was statistically diversified (Tab. 4). Similar hardness values were characteristic of organic pastas produced in laboratory conditions from flour from the grain of spring wheat cultivars by Gońda et al. (2018). A higher value of that parameter was noted in the case of organic pastas from wholemeal flour analysed by Olivera and Salvadori (2009).

Gumminess and chewiness are parameters describing the energy required for the fragmentation of the product to a form permiting its swallowing (Trinh and Glasgow 2012). Gumminess of the analysed pastas varied from 1.09 to $2.83 \mathrm{~N}$, and the differences were statistically significant, while chewiness was statistically 


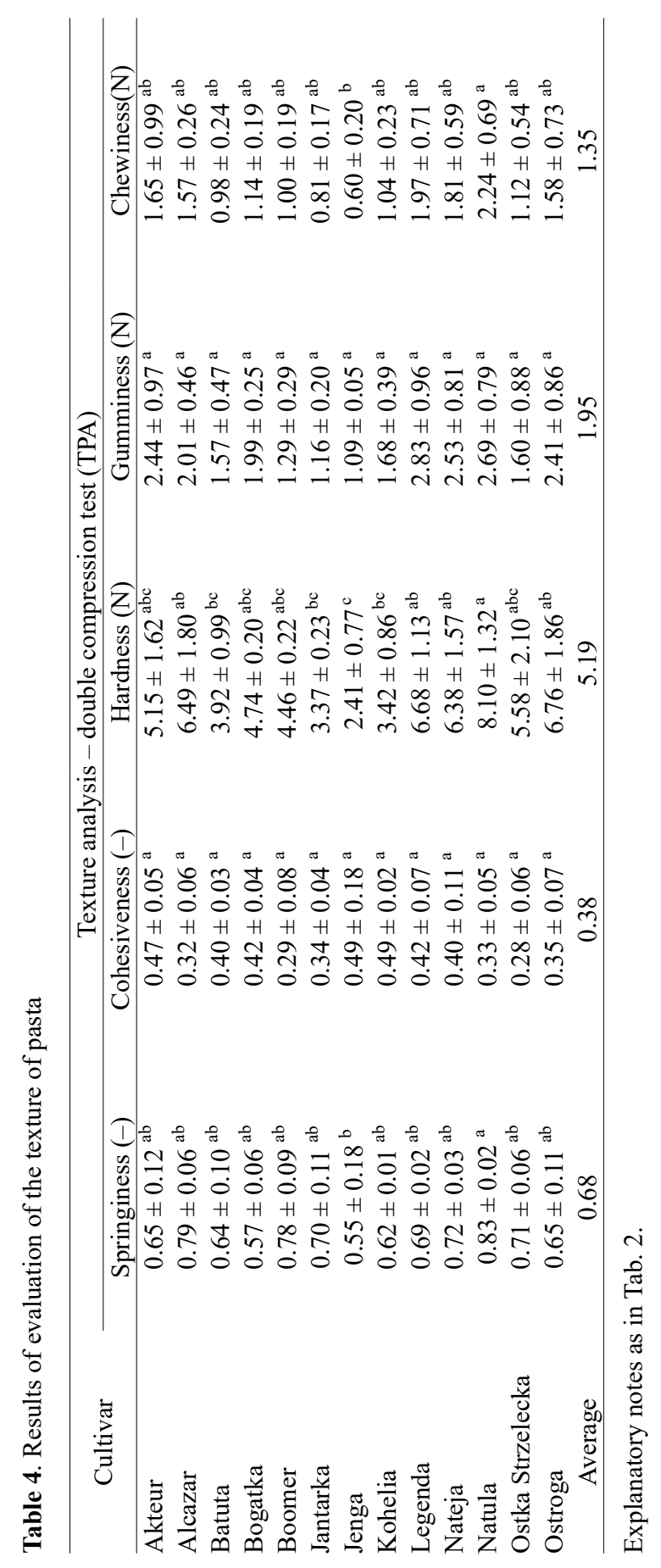


diversified and varied from 0.60 to $2.24 \mathrm{~N}$ (Tab. 4). In an earlier study (Gońda et al. 2018), both the gumminess and the chewiness of organic pastas from flour from the grain of spring wheat cultivars were somewhat lower.

\section{CONCLUSIONS}

1. Pasta doughs prepared from flour from the grain of the analysed winter wheat cultivars differed significantly in terms of the colour parameters $L^{*}, a^{*}, b^{*}$. After the 3-hour thermostating the values of parameter $L^{*}$ decreased, which indicates darkening of their colour (tending to grey). Changes in the values of parameters a* and $b^{*}$, on the other hand, indicate an increase of the contribution of the red colour and a decrease of that of the yellow colour. The differences in the colour of fresh pasta doughs and those after the temperature cycle were significant $(\Delta \mathrm{E}>3,5)$.

2. Visual comparison of the colour of fresh pasta doughs and those after the thermostating confirmed the colour changes determined instrumentally. None of the analysed pasta dough samples was classified in the group with low susceptibility to darkening. Most of the analysed doughs were characterised by medium susceptibility to darkening. Doughs prepared from flour from the grain of the cultivars Alcazar, Jenga, Legenda and Natej were classified in the group with high susceptibility to darkening. In industrial conditions, this would be the basis for their rejection in the choice of raw material for pasta production.

3. In spite of the relatively low content of total protein (8.3-9.8\% DM), the analysed pastas were characterised by good culinary properties. Dry matter loss during cooking was relatively small (3.1-6.5\%), and the weight increase of the pastas after cooking was approx. three-fold (2.9-3.2). The pastas were diversified in terms of such parameters as hardness, springiness and chewiness.

4 . The mean number of points given by the team evaluating the sensory features of the pastas was 4.3 (in a 0-5 pts. scale). The highest rated were pastas from flour from the grain of wheat cultivars Alcazar, Bogatka and Natula, and the lowest - the pasta from flour from the grain of wheat cultivar Ostroga.

5. Based on the results obtained, flours from the grain of the wheat cultivars Bogatka and Natula were selected as potential raw material for the production of organic pasta.

Conflict of interest: The Authors does not declare conflict of interest.

\section{REFERENCES}

Bagdi A., Szabo F., Gere A., Kokai Z., Sipos L., Tomoskozi S., 2014. Effect of aleurone-rich flour on composition, cooking, textural, and sensory properties of pasta. LWT - Food Sci. Technol., 59(2), 996-1002, https://doi.org/10.1016/j.lwt.2014.07.001 
Baiano A., Conte A., Pati S., Del Nobile M.A., 2007. Influence of protein content and drying temperature on pasta quality. Tecnica Molitoria International, 58, 84-91.

Biernacka B., Dziki D., Gawlik-Dziki U., Różyło R., Siastała M., 2017. Physical, sensorial, and antioxidant properties of common wheat pasta enriched with carob fiber. LWT-Food Sci. Technol., 77, 186-192, https://doi.org/10.1016/j.lwt.2016.11.042

Biernacka B., Dziki D., Różyło R., Wójcik M., Miś A., Romankiewicz D., Krzysiak Z., 2018. Relationship between the properties of raw and cooked spaghetti - New indices for pasta quality evaluation. Int. Agrophys., 32, 217-223, https://doi.org/10.1515/intag-2017-0012

Cacak-Pietrzak G., Ceglińska A., Jończyk K., Kuś J., 2008. Use of selected winter wheat cultivars from organic farming for bread production (in Polish). Fragm. Agron., XXV, 1(97), 67-74.

Cacak-Pietrzak G., Romankiewicz D., Ceglińska A., Lenart E., 2016. Evaluation of quality of commercial organic pasta (fusilli spirale form) (in Polish). Przegl. Zboż-Młyn., 60(3), 36-39.

De Marco E.R., Steffolano M.E., Martinez C.S., Leon A.E., 2014. Effects of spirulina biomass on the technological and nutritional quality of bread wheat pasta. LWT - Food Sci. Technol., 58(1), 102-108, https://doi.org/10.1016/j.lwt.2014.02.054

Deng L., Manthey F.A., 2017. Effect of single-pass and multipass milling systems on whole wheat durum flour and whole wheat pasta quality. Cereal Chem., 94(6), 963-969, https://doi.org/ 10.1094/CCHEM-05-17-0087-R

Dziki D., Biernacka B., Laskowski J., 2012. Effect of cooking time and addition of comon wheat flour to semolina on mechanical properties of spaghetti (in Polish). Acta Agroph., 19(2), 277-287.

Dziki D., Cacak-Pietrzak G., Gawlik-Dziki U., Świeca M., Miś A., Różyło R., Jończyk K., 2017. Physicochemical properties and milling characteristics of spring wheat from different farming systems. J. Agr. Sci. Tech, Vol. 19, 1253-1266, http://journals.modares.ac.ir/article-23-7491-en.html

Gońda M., Cacak-Pietrzak G., Jończyk K., 2018. Assessment of the use of flour from the grain of spring common wheat cultivated under organic farming for pasta production. Acta Agroph., 25(2), 163-174, https://doi.org/10.31545/aagr/92544

Gull A., Prasad K., Kumar P., 2015. Effect of Millet flours and carrot pomace on cooking qualities, color and texture of developed pasta. LWT - Food Sci. Technol., 63, 470-474, https://doi. org/10.1016/j.lwt.2015.03.008

GUS, 2020. Statistical Yearbook of Agriculture (in Polish). Wydawnictwo GUS, Warszawa.

Joubert M., Morel M.H., Lullien-Pellerin V., 2018. Pasta color and viscoelasticity: Revisiting the role of particle size, ash, and protein content. Cer. Chem., 95, 386-398, https://doi.org/10.1002/cche.10038

Klepacka J., Fornal Ł., 2008. Determination of correlation between the content of selected phenolic compounds and the milling value of wheat grain (in Polish). Żywn. Nauk. Technol. J., 6 (61), 55-64.

Leszczyńska D., 2010. Effect of selected factors on grain quality (in Polish). Świat Zbóż, 12, 30-33.

Ma D.Y., Zhang J., Lou X.T., Wang X.N., Wang C.Y., Guo T.C., 2014. Color, cooking and texture of yellow alkaline noodles enriched with millet and corn flour. IFRJ, 21(3), 1187-1192.

Marzec A., Cacak-Pietrzak G., Gondek E., 2011. Mechanical and acoustic properties of spring wheat versus its technological quality factors. J. Texture Stud., 42, 319-329, https://doi.org/10.1111/ j.1745-4603.2011.00284.x

Mondelli G., 2004. Pasta stickiness and semolina quality characteristics. Professional Pasta, 24, 14-20.

Obuchowski W., 1997. Technology of industrial production of pasta (in Polish). Wyd. AR Poznań, 53-54, 65-84.

Olivera D., Salvadori V., 2009. Effect of freezing rate in textural and rheological characteristics of frozen cooked organic pasta. J. Food Eng., 90, 271-276, https://doi.org/10.1016/j.jfoodeng.2008.06.041

Operation Manual, 1997. Texture Analyser TA.XT2 (in Polish). Stable Micro System. 
Özyurt G., Uslu L., Yuvka I., Gökdoğan S., Acti G., Ak B., Işik O., 2015. Evaluation of the cooking quality characteristics of pasta enriched with Spirulina platensis. J. Food Quality, 38, 268-272, https://doi.org/10.1111/jfq.12142

Petitot M., Boyer L., Minier Ch., Micard V., 2010. Fortification of pasta with split pea and faba bean flours: Pasta processing and quality evaluation. Food Res. Int., 43, 634-641, https://doi. org/10.1016/j.foodres.2009.07.020

Petitot M., Brossard Ch., Barron C., Larre C., Morel M., Micard V., 2009. Modification of pasta structure induced by high drying temperatures. Effects on the in vitro digestibility of protein and starch fractions and the potential allergenicity of protein hydrolysates. Food Chem., 116, 401412, https://doi.org/10.1016/j.foodchem.2009.01.001

Piwińska M., Wyrwisz J., Kurek M.A., Wierzbicka A., 2016. Effect of drying methods on the physical properties of durum wheat pasta. CYTA - J. Food, 14(4), 523-528, https://doi.org/10.1080/194 76337.2016 .1149226

PN-A-74020:1993. Cereal products. Common pasta flour (in Polish).

PN-EN ISO 20483:2014-02. Grain of cereals and seeds of legumes - Determination of nitrogen content and conversion to protein content - Kjeldahl method (in Polish).

PN-EN ISO 2171:2010. Grain of cereals, seeds of legumes, and their products - Determination of ash content with the incineration method (in Polish).

Rachon L., 2004. Estimation of the usability of Polish and foreign lines and cultivars of durum wheat (Triticum durum Desf.) for pasta production (in Polish). Biul. IHAR, 231, 129-137

Rachoń L., Dziamba Sz., Obuchowski W., Kołodziejczyk P., 2002. Estimation of the usability of grain of cultivars of durum wheat (Triticum durum) and common wheat (Triticum aestivum ssp. vulgare) for pasta production (in Polish). Annales UMCS, Sec. E, 57, 77-86.

Romankiewicz D., Hassoon W.H., Cacak-Pietrzak G., Sobczyk M., Wirkowska-Wojdyła M., Ceglińska A., Dziki D., 2017. The effect of chia seeds (Salvia hispanica L.) addition on quality and nutritional value of wheat bread. Journal of Food Quality, article ID 7352631, 7 pages, https://doi.org/10.1155/2017/7352631

Sicignano A., Monaco R., Masi P., Cavella S., 2015. From raw material to dish: pasta quality step by step. J. Sci. Food Agr., 95(13), 2579-87, https://doi.org/10.1002/jsfa.7176

Sobota A., Skwira A., 2009. Physical properties and chemical composition of pressed pastas (in Polish). Acta Agroph., 13(1), 245-260.

Stępniewska S., 2016. Milling value of grain of selected wheat cultivars from harvests of 2012-2014 (in Polish). Acta Agroph., 23(1), 105-117.

Trinh T.K., Glasgow S., 2012. On the texture profile analysis test. Proceedings of the International Conference of Cheneca 2012, Wllington, New Zeland, 23-26 September, Australia: Engineers Australia.

Vetrimani R., Sudha M.L., Rao P.H., 2005. Effect of extraction rate of wheat flour on the quality of vermicelli. Food Res. Int., 38, 411-416, https://doi.org/10.1016/j.foodres.2004.10.013

Wójtowicz A., 2006. Effect of extrusion parameters on selected texture properties of instant pastas produced from semolina (in Polish). Acta Agroph., 8(4), 1049-1060. 